(C) 2016

Вінцковська Ю. Ю., аспірант

(науковий керівник - доктор сільськогосподарських наук Л. М. Шевчук)

Інститут садівництва (IC) НААН України

\title{
ВПЛИВ ПОЗАКОРЕНЕВОЇ ОБРОБКИ НАСАДЖЕНЬ ЯБЛУНІ (MALUS DOMESTICA ВОRКН.) БІОПРЕПАРАТАМИ НА ФОРМУВАННЯ ПОКАЗНИКІВ ЯКОСТІ ПЛОДІВ
}

\author{
Рецензент - кандидат сільськогосподарських наук Ю. Д. Гончарук
}

Наведено результати досліджень (2013-2015 рр.) щуодо визначення впливу позакореневої обробки дерев яблуні препаратами «Атонік Плюс» $i$ «Вапор Гард» на формування показників якості плодів (вміст сухих розчинних речовин (СРP), органічних титрованих кислот і иукрів). Об'єктом був літній сорт Ямба. Встановлено, щзо застосування першого з названих препаратів перед другою хвилею опадання зав'язі та збором урожаю сприяло збільшенню кількості сухих розчинних речовин і цукрів та зменшенню накопичення органічних титрованих кислот у плодах, $i$ тим самим - покращенню смакових якостей останніх. У разі обробки антитранспірантом «Вапор Гард» під час першої хвилі опадання зав 'язі та перед збиранням плодів у них підвищився вміст цукрів порівняно з контролем.

Ключові слова: плоди яблуні, позакореневе удобрення, маса плоду, вміст сухих розчинних речовин, органічних титрованих кислот, иукрів.

Постановка проблеми. Для отримання високих урожаїв в інтенсивних плодових насадженнях велике значення має застосування удобрення, що сприяє забезпеченню потреб рослини в мінеральному живленні. Проте внесення добрив у грунт не завжди дає змогу повністю досягти цієї мети [3]. Таку ситуацію може виправити позакореневе підживлення протягом вегетаційного періоду. Воно коригує живлення дерев, а також запобігає розвитку функціональних розладів у рослинах [5]. У зв'язку з вимогами стосовно максимальної екологізації сільськогосподарського виробництва, збільшення безпеки для навколишнього середовища та людини пріоритет надається препаратам нешкідливим для теплокровних організмів [11]. Асортимент яблуні постійно оновлюється, а це ставить нові завдання щодо застосування екологічно безпечних препаратів та визначення особливостей їх впливу на показники якості плодів.

Аналіз останніх досліджень i публікацій, у яких започатковано розв'язання проблеми. Яблуня впевнено займає перше місце серед плодових і ягідних культур в Україні. Однак у науковій літературі недостатня кількість інформації щодо впливу позакореневого живлення біопрепаратами на якість плодів яблуні, хоч вони мають важливе значення в харчуванні людини. Аналізуючи споживчий кошик населення нашої країни, можна впевнено стверджувати, що в ньому серед продуктів харчування основну позицію займають картопля та хліб. Натомість потреба у плодах і ягодах задовольняється лише на $35-45 \%$ [9].

Плоди і овочі - головне джерело багатьох мінеральних елементів, необхідних людському організму [8], зокрема яблука містять значну кількість цукрів, органічних кислот, пектинових речовин. За даними різних авторів, середньорічна фізіологічно необхідна норма їх споживання людиною становить 60-70 кг. Для забезпечення повноцінного харчування населення необхідно якомога краще збалансувати річний план постачання високоякісних свіжих плодів. На даний час важливого значення набуває взаємодія макро- та мікроелементів із грунтом, рослинами, тваринами й людиною та у зв'язку з інтенсифікацією сільського господарства через необхідність охорони навколишнього середовища від можливого забруднення добривами, гербіцидами, пестицидами, відходами промисловості й іншими техногенними матеріалами [15].

За літературними даними, позакореневе підживлення позитивно впливає на силу цвітіння, збільшує кількість квіткових бруньок, стимулює плодоутворення, зменшує опадання зав'язі і плодів, сприяє прикріпленню їх до кільчатки $[1,6]$.

У випадку позакореневого внесення мінеральних добрив можна внести через листя у 1,5-2 рази більше поживних і фізіологічно активних речовин, ніж з іншими формами удобрення [11].

Під впливом позакореневої обробки макро-, мікроелементами та хелатними добривами у плодах яблуні спостерігалося достовірне збільшення порівняно 3 контролем вмісту СРР - на 12-32 \%, аскорбінової кислоти - на 6-15\%, розчинних цукрів - на 8-13\%, розчинного пектину - на 6-15\%, протопектина - на 8-15\%. Використання комплексних добрив справляло позитивну 
дію на інтегральний рівень поживної та вітамінної цінності яблук [10].

Молдавські вчені встановили, що застосування мікроелементів покращує забарвлення плодів, збільшує цукристість, вміст СРР, вітаміну С, дубильних речовин, посилює синтез пектинових речовин, знижує кислотність. В оброблених мікроелементами плодів збільшується стійкість до грибних захворювань, розтріскування та механічних пошкоджень під час збору, пакування i транспортування. Фізіологічно активні речовини спрямовано діють на процеси розвитку плодів: можливо суттєво покращити їх якість, прискорити або затримати дозрівання, покращити лежкість, а також підвищити стійкість до фізіологічних і мікробіологічних втрат за довготривалого зберігання [1].

Вітчизняні науковці проводили дослідження 3 використанням комплексу макро- та мікроелементів на показники якості плодів яблуні, але біопрепарати нового покоління не вивчались. Літературні дані не описують у повній мірі вплив біопрепаратів саме на споживчі і товарні якості плодів яблуні, вирощених у правобережній частині Лісостепу України, тому це питання потребує більш детального вивчення.

Мета досліджень полягає у вивченні ефективності впливу препаратів «Атонік Плюс» і «Вапор Гард» на формування товарних і споживчих якостей плодів яблуні літнього сорту Ямба, вирощених у правобережній частині Лісостепу України.

Завданням є визначення дії фітостимулятора «Атонік Плюс» та антитранспіранта «Вапор Гард» на формування товарних і споживчих якостей плодів яблуні літнього сорту.

Методика досліджень. Дослідження проводили в лабораторії післязбиральної обробки плодів Інституту садівництва НААН України протягом 2013-2015 рр. Зразки відбирали згідно 3 ДСТУ ISO 874 [4] в дослідних насадженнях державного підприємства «ДГ Новосілки» названого інституту, висаджених у 2002 році за схемою 4х3 м, форма крони кругла, підщепа 54118 , без поливу, система утримання грунту природне задерніння. Біохімічний склад плодів визначали відповідно до «Методики оцінки якості плодово-ягідної продукції» [7].

Позакореневу обробку дерев проводили з використанням препаратів «Атонік Плюс» та «Вапор Гард». «Атонік Плюс»- це фітостимулятор, регулятор росту і плодоношення на природній основі $з$ яскраво вираженою регенеративною та антистресовою дією. «Вапор Гард»-це натуральний антитранспірант, поверхнево активна речо- вина, що застосовується зокрема на плодовоягідних культурах для зменшення транспірації, покращання якості продукції та збільшення врожайності. Дані препарати характеризуються високими показниками безпеки для людини та довкілля.

У дослідах обприскували робочим розчином листову поверхню дерев. У кожному варіанті по 6 облікових дерев. Варіанти обробки, період обробки та норми витрати препаратів представлені на схемі досліду (табл. 1).

Для всіх варіантів досліду контролями була обробка дерев водою та біологічно активною речовиною в рекомендовані виробником строки, зокрема «Атоніком Плюс» - у період цвітіння, під час інтенсивного росту і розвитку плодів та перед збором урожаю (варіант «Атонік I»), «Вапор Гард» - за 3-4 тижні до збирання плодів (варіант «ВГ III»).

Сума активних температур $10^{\circ} \mathrm{C}$ i вище від початку цвітіння до збору врожаю у 2013 році становила $1802,5^{\circ} \mathrm{C}$, кількість опадів - 133 мм, а ГТК - 0,74. У 2014 р. кількість опадів за згаданий період була вищою у 2,4 рази, ніж у попередньому році та становила 323,2 мм, сума активних температур $10^{\circ} \mathrm{C}$ і вище знаходилась на рівні 2013 р., водночас коефіцієнт зволоження становив 1,8 .

Період цвітіння та росту плодів у 2015 році характеризувався меншою сумою активних температур $10{ }^{\circ} \mathrm{C}$ і вище, ніж у 2013 і 2014 (на 97,6 та $94,7^{\circ} \mathrm{C}$ відповідно), а кількість опадів на рівні 63,2 мм забезпечила ГТК 0,37.

Результати досліджень. Оптимальне зволоження території в період від цвітіння до збору врожаю у 2013 році за показником ГТК $(0,74)$ сприяло накопиченню маси плодами досліджуваного сорту в усіх варіантах.

Зокрема, у контролі з $\mathrm{H}_{2} \mathrm{O}$ даний показник дорівнював 127, біопрепаратами - 130 г, що на 15 г менше, ніж у разі використання «Атоніка Плюс» перед другою хвилею опадання зав'язі та на 11 г менше, ніж у варіанті 2 (обприскування «Вапор Гардом»).

Велика кількість опадів (323,3 мм) і ГТК на рівні 1,8 у період споживчої стиглості плодів позначилися на накопиченні ними маси у 2014 р., котра у варіанті з обробкою водою становила 117 г. У випадку позакореневого обприскування «Атоніком Плюс» перед другою хвилею опадання зав'язі даний показник був на 20 і 13 г вище порівняно 3 контрольним варіантом обробки цим препаратом та водою відповідно. Істотної різниці між цими варіантами в разі використання «Вапор Гард» не помічено. 


\begin{tabular}{|c|c|c|c|c|c|}
\hline \multicolumn{6}{|c|}{ 1. Схема досліду } \\
\hline Варіанти & \multicolumn{5}{|c|}{ Варіанти обробки } \\
\hline Обробка $\mathrm{H}_{2} \mathrm{O}$ (контроль) & $\begin{array}{l}\text { У період } \\
\text { цвітіння }\end{array}$ & $\begin{array}{c}\text { За першої } \\
\text { хвилі } \\
\text { опадання } \\
\text { зав'язі } \\
\end{array}$ & $\begin{array}{r}\text { За д1 } \\
\text { хв } \\
\text { опад } \\
\text { зав } \\
\end{array}$ & & $\begin{array}{l}\text { За 3-4 тижні до } \\
\text { збору врожаю }\end{array}$ \\
\hline $\begin{array}{c}\text { «Атонік Плюс І» («Атонік І») } \\
\left(0,2 \text { л/га) }\left(\mathrm{K}_{1}\right)\right.\end{array}$ & $\begin{array}{l}\text { У період } \\
\text { цвітіння }\end{array}$ & \multicolumn{3}{|c|}{$\begin{array}{c}\text { Перед другою хвилею } \\
\text { опадання зав'язі }\end{array}$} & $\begin{array}{l}\text { За 3-4 тижні до } \\
\text { збирання плодів }\end{array}$ \\
\hline $\begin{array}{c}\text { «Атонік Плюс ІІ» («Атонік II») } \\
\left(0,2 \text { л/га) }\left(\mathrm{B}_{1}\right)\right.\end{array}$ & \multicolumn{4}{|c|}{ Перед другою хвилею опадання зав'язі } & $\begin{array}{l}\text { За 3-4 тижні до } \\
\text { збору врожаю }\end{array}$ \\
\hline «Вапор Гард III» (1 \% розчин) $\left(\mathrm{K}_{2}\right)$ & \multicolumn{5}{|c|}{ За 3-4 тижні до збирання плодів } \\
\hline $\begin{array}{c}\text { «Вапор Гард } \mathrm{I} »(« \mathrm{~B} Г \mathrm{I} ») \\
(1 \% \text { розчин })\left(\mathrm{B}_{2}\right)\end{array}$ & \multicolumn{3}{|c|}{$\begin{array}{c}\text { Під час першої хвилі опадання } \\
\text { зав'язі }\end{array}$} & \multicolumn{2}{|c|}{$\begin{array}{c}\text { За 3-4 тижні до збору } \\
\text { врожаю }\end{array}$} \\
\hline $\begin{array}{c}\text { «Вапор Гард II» }(\mathrm{BГ} \text { II }) \\
(1 \% \text { розчин })\left(\mathrm{B}_{3}\right)\end{array}$ & \multicolumn{3}{|c|}{$\begin{array}{c}\text { Під час другої хвилі опадання } \\
\text { зав'язі }\end{array}$} & \multicolumn{2}{|c|}{$\begin{array}{l}\text { За 3-4 тижні до } \\
\text { збирання плодів }\end{array}$} \\
\hline
\end{tabular}

У 2015 році ГТК становив 0,37 , що нижче, ніж у 2014 та 2013 роках на 1,43 і 0,77 відповідно. За таких умов маса яблук у період збирання залежно від варіанту обробки в разі застосування «Атоніка Плюс» у контролі 1 та у варіант 1 дорівнювала 104 і 111 г відповідно. У разі використання Вапор Гарда під час другої хвилі опадання зав'язі цей показник був на 4 г вищим, ніж перед збором урожаю.

В середньому за 2013-2015 pр. у контрольних варіантах $з$ обприскуванням водою, «Атоніком Плюс» та «Вапор Гардом» маса плодів була менша, ніж у варіантах досліду. Під час застосування «Атоніка Плюс» перед другою хвилею опадання зав'язі прибавка у масі в середньому по роках дослідження становила $+7 \%$ до контролю $3 \mathrm{H}_{2} \mathrm{O}$ та $+4 \%$ до контролю 3 цим препаратом.

У 2013 році сума опадів у варіанті з обробкою $\mathrm{H}_{2} \mathrm{O}$ за період від початку цвітіння до збирання плодів становила 133 мм, вміст сухих розчинних речовин у них на час настання споживчої стиглості був на рівні 9,8 \%. Накопичення їх у контрольних варіантах з обробкою «Атоніком Плюс» i «Вапор Гардом» було більше на 1 і 3 \% відповідно, порівняно з обприскуванням водою. Кількість СРР у випадку використання першого 3 препаратів перед другою хвилею опадання зав'язі становила 10,5\%, що на 7 і $6 \%$ більше, ніж у контролі з $\mathrm{H}_{2} \mathrm{O}$ та «Атоніком Плюс» відповідно. Обробка «Вапор Гардом» на накопичення сухих розчинних речовин у плодах істотно не вплинула.

У 2014 р. сума опадів у період від початку цвітіння до збору врожаю (323,3 мм) вплинула на нагромадження СРР - їх вміст у всіх варіантах був вищим, ніж у попередній рік. Однак існують відмінності за цим показником між варіантами обприскування. Так, за обробки водою плоди накопичили даних речовин 10,3 \%, 10,7 i $10,4 \%$ у контрольних варіантах 3 «Атоніком Плюс» і «Вапор Гардом» відповідно (табл. 2). Під час використання першого з цих препаратів більшу кількість сухих розчинних речовин відмічено за трикратного обприскування ним. Обробка «Вапор Гардом» у досліджуваних варіантах у 2014 р. підвищила вміст СРР на 6 та $5 \%$ відповідно порівняно з контролями.

Незначна кількість опадів (63,2 мм) за період цвітіння і достигання плодів у 2015 році сприяла накопиченню плодами сухих розчинних речовин. Так, їх кількість у контрольному варіанті 3 $\mathrm{H}_{2} \mathrm{O}$ становила 11,4 \%, у разі використання «Атоніка Плюс» найвищий вміст СРР (12,0\%) був за обприскування ним перед другою хвилею опадання зав' язі. Застосування «Вапор Гарда» не справило значного впливу на їх накопичення у яблуках.

У середньому за 2013-2015 рр. найменшу кількість їх зафіксовано було у варіанті з обробкою $\mathrm{H}_{2} \mathrm{O}(10,5 \%)$. Обприскування дерев «Атоніком 
Плюс» та «Вапор Гардом» у досліджуваних варіантах сприяло на $2 \%$ більшому накопиченню СРР, ніж у контролі з даними препаратами.

Цукри $є$ істотною складовою СРР, тому тенденції їх накопичення співпадають [13]. Однак у 2013 і 2015 pp. така закономірність порушилась. Наприклад, у 2013 р., коли сума активних температур $10^{\circ} \mathrm{C}$ і вище в період від початку цвітіння до збору врожаю становила $1802,5{ }^{\circ} \mathrm{C}$, вміст цукрів (від 7,3 \% (контроль з $\mathrm{H}_{2} \mathrm{O}$ ) до 7,8 \% - обприскування «Вапор Гардом» під час першої хвилі опадання зав'язі) був вищим порівняно 3 наступними роками. Позакореневе внесення «Атоніка Плюс» перед другою хвилею опадання зав'язі позитивно вплинуло на накопичення цукрів. Їх кількість у даному варіанті становила 7,7 \%, тоді як у контролі з обробкою вказаним препаратом $-7,4$, а $3 \mathrm{H}_{2} \mathrm{O}-7,3 \%$. Використання «Вапор
Гард» (контрольне та під час другої хвилі опадання зав'язі) сприяло збільшенню нагромадження цукрів на 0,4 , а під час першої хвилі - на $0,5 \%$ у порівнянні з обприскуванням водою.

Велика сума опадів (323,3 мм) у 2014 році негативно позначилась на накопиченні не лише $\mathrm{CPP}$, а й цукрів - вміст цих речовин був нижчий, ніж в інші роки.

У 2015 році за суми активних температур $10{ }^{\circ} \mathrm{C}$ і вище у період від початку цвітіння до збирання плодів $1704,9^{\circ} \mathrm{C}$, найменшу кількість цих речовин $(6,1 \%)$ зафіксовано у варіанті з обробкою водою. У яблук, що були в стані споживчої стиглості, цей показник за три- і двократного обприскування «Атоніком Плюс» різнився мало, але порівняно 3 контролем $\left(\mathrm{H}_{2} \mathrm{O}\right)$ виявився на $13 \%$ вищим.

\section{2. Вміст у плодах яблуні сорту Ямба органічних речовин залежно від обробки та року вирощування}

\begin{tabular}{|c|c|c|c|c|}
\hline \multirow{2}{*}{ Варіант обробки } & \multirow{2}{*}{ Рік досліджень } & \multicolumn{3}{|c|}{ Вміст, \% } \\
\hline & & $\begin{array}{c}\text { сухі розчинні } \\
\text { речовини }\end{array}$ & цукри & $\begin{array}{c}\text { органічні титровані } \\
\text { кислоти }\end{array}$ \\
\hline \multirow{4}{*}{ Контроль (К) } & 2013 & 10,5 & 7,6 & 0,81 \\
\hline & 2014 & 10,3 & 6,8 & 1,16 \\
\hline & 2015 & 11,4 & 6,1 & 1,26 \\
\hline & середнє & 10,7 & 6,8 & 1,08 \\
\hline \multirow{4}{*}{ «Атонік I» (K1) } & 2013 & 9,9 & 7,4 & 0,87 \\
\hline & 2014 & 10,7 & 6,9 & 1,02 \\
\hline & 2015 & 12,2 & 6,9 & 1,25 \\
\hline & середнє & 10,9 & 7,1 & 1,05 \\
\hline \multirow{4}{*}{ «Атонік II» (B1) } & 2013 & 10,5 & 7,7 & 0,67 \\
\hline & 2014 & 10,5 & 7,0 & 1,12 \\
\hline & 2015 & 12,0 & 6,6 & 1,21 \\
\hline & середнє & 11,0 & 7,1 & 1,00 \\
\hline \multirow{4}{*}{$\begin{array}{c}\text { «Вапор Гард III» } \\
\text { (К2) }\end{array}$} & 2013 & 10,1 & 7,7 & 0,70 \\
\hline & 2014 & 10,4 & 6,9 & 1,09 \\
\hline & 2015 & 11,5 & 6,9 & 1,19 \\
\hline & середнє & 10,7 & 7,2 & 0,99 \\
\hline \multirow{4}{*}{$\begin{array}{l}\text { «Вапор Гард I» } \\
\text { (В2) }\end{array}$} & 2013 & 9,9 & 7,8 & 0,76 \\
\hline & 2014 & 10,9 & 7,0 & 1,06 \\
\hline & 2015 & 11,4 & 7,3 & 1,25 \\
\hline & середнє & 10,7 & 7,4 & 1,02 \\
\hline \multirow{4}{*}{$\begin{array}{c}\text { «Вапор Гард II» } \\
\text { (B3) }\end{array}$} & 2013 & 10,1 & 7,7 & 0,67 \\
\hline & 2014 & 10,9 & 6,3 & 1,09 \\
\hline & 2015 & 11,6 & 6,6 & 1,21 \\
\hline & середнє & 10,9 & 6,9 & 0,99 \\
\hline
\end{tabular}




\section{СТОРІНКА МОЛОДОГО ВЧЕНОГО}

Значну різницю у вмісті цукрів відмічено у варіантах, оброблених «Вапор Гардом» під час першої хвилі опадання зав'язі - на 0,4 та 0,7 \% більше, ніж за контрольного обприскування цим антитранспірантом і водою відповідно. Дерева, оброблені «Вапор Гардом» під час другої хвилі опадання зав'язі, формували плоди зі вмістом цукрів $6,6 \%$, що на 0,5 \% більше, ніж у контролі 3 водою, але менше, порівняно 3 обприскуванням цим препаратом.

У середньому за роки спостережень кількість цукрів у яблуках коливалася від 6,7 \% (обприскування водою) до 7,4 \% (застосування «Вапор Гарда» під час першої хвилі опадання зав'язі). Найкраще вплинула на накопичення цих речовин у плодах обробка насаджень «Атоніком Плюс» перед другою хвилею опадання зав’язі та «Вапор Гардом» під час першої хвилі (кількість цукрів у плодах дорівнювала 7,2 і 7,4 \% відповідно).

Важливим фактором нормального смаку яблук $\epsilon$ органічні кислоти - занадто великий їх вміст порушує цукрово-кислотну рівновагу. Висока кислотність заважає використанню плодів у свіжому вигляді та обмежує їх придатність до переробки [14]. Істотний вплив на нагромадження даних речовин справляє сума активних температур $10{ }^{\circ} \mathrm{C}$ і вище у період росту і розвитку плодів. У 2013 р., коли сума цих температур $1802,5^{\circ} \mathrm{C}$, зафіксовано найменшу кількість органічних кислот у яблуках. У контрольному варіанті з обприскуванням «Атоніком Плюс» вміст титрованих кислот становив $0,87 \%$, що на $0,2 \%$ вище, ніж за використання «Атоніка Плюс» перед другою хвилею опадання зав'язі. У випадку обробки «Вапор Гардом» у першу хвилю опадання зав'язі плоди містили 0,76 \% органічних кислот, а у другу хвилю - 0,67 \%. Водночас під час застосування фітостимулятора та антитранспіранта кількість органічних кислот була меншою, ніж у контролі з водою.

У 2014 р. сума активних температур $10{ }^{\circ} \mathrm{C}$ i вище дорівнювала $1799,6{ }^{\circ} \mathrm{C}$, тобто була майже на рівні 2013 року. Проте велика кількість опадів (323,3 мм) за період від початку цвітіння до на-

\section{БІБЛІОГРАФІЯ}

1. Лежкоспособность плодов и факторы, снижающие их потери при длительном хранении / [Бажуряну Н. С., Попушой И. С., Коган Э. Д., Тодираш В. А.]. - Кишенев : Штиица, Ин-т физиологии растений. - Академия НАУК Республики Молдова. - 1993. - 96 с.

2. Балабак A. В. Еколого-біологічні аспекти застосування біостимуляторів росту рослин / стання споживчої стиглості яблук сприяла підвищенню вмісту органічних титрованих кислот у них, особливо у контролі $3 \mathrm{H}_{2} \mathrm{O}-1,16 \%$. Трикратне обприскування «Атоніком Плюс» зменшило накопичення цих речовин $(1,02$ \%) у 2014 році. У вказаному році за обробки антитранспірантом під час першої хвилі опадання зав'язі кількість органічних кислот у плодах становила 1,06 \%, що на 0,6 і 0,3 \% менше, ніж під час використання даного препарату у контролі з ним та у другій хвилі опадання зав'язі відповідно.

У 2015 р. найменша сума активних температур $10{ }^{\circ} \mathrm{C}$ i вище за три роки спостережень $\left(1704,9^{\circ} \mathrm{C}\right)$ у період від початку цвітіння до збору плодів сприяла більшому нагромадженню титрованих кислот, кількість яких коливалась від 1,19\% (у контролі 3 використанням «Вапор Гарда») до 1,26 (у варіанті з $\mathrm{H}_{2} \mathrm{O}$ ).

Результати вивчення вмісту органічних кислот у плодах досліджуваного сорту показали, що в середньому за роки спостережень найнижчий вміст органічних титрованих кислот був за використання «Вапор Гарда» у контролі 3 ним та під час другої хвилі опадання зав'язі $(0,99 \%)$ i «Атоніка Плюс» - перед другою хвилею (1,00 \%).

Органолептичні показники плодів, а саме: інтенсивність забарвлення, смак та консистенція м'якоті помітно вирізнялись у варіанті з обприскуванням яблук «Атоніком Плюс» перед другою хвилею опадання зав'язі, а також «Вапор Гардом» - під час першої хвилі. Результати дегустації показали, що плоди оброблені антитранспірантом під час першої хвилі опадання зав'язі характеризуються високими смаковими якостями.

Висновок. Обприскування дерев яблуні сорту Ямба препаратом «Атонік Плюс» перед другою хвилею опадання зав'язі та збором урожаю, а також «Вапор Гардом» - у першу та другу хвилі та під час збирання плодів - сприяє покращанню якості яблук, а саме: підвищенню вмісту сухих розчинних речовин і цукрів.

Застосування «Атоніка Плюс» у другій половині вегетації, а «Вапор Гарда» під час першої хвилі опадання зав'язі забезпечує отримання плодів з високими показниками якості.

А. В. Балабак : зб. тез IV міжвузівської наук.практ. конф. 16-17 жовтня [«Екологія - шляхи гармонізації відносин природи та суспільства»]. Умань, 2014. - С. 38-39.

3. Вплив позакореневої обробки макроелементами на ріст, урожайність та функціональний стан дерев яблуні / [Горб О. С., Китаєв О. І., Скряга В. А. та ін.] // Садівництво. - Вип. 63. - 2010. 
4. Фрукти і овочі свіжі. Відбирання проб : ДСТУ ISO 874-2002.

5. Ильинский А. А., Рубин С.С. Плодовый сад на юге / А. А. Ильинский, С. С. Рубин. - М. : Колос, $1968 .-367$ с.

6. Капичникова Н. Г. Влияние некореневого внесения удобрений на урожайность яблони / Н. Г. Капичникова. - Плодоводство : РУП «Институт плодоводства». - Том 21. - 2009. - С. 82.

7. Кондратенко П. В. Методика оцінки якості плодово-ягідної продукції / П.В.Кондратенко, Л. М. Шевчук, Л. М. Левчук. - К., 2008. - 80 с.

8. Кондратенко П. В. Оцінка продовольчого забезпечення населення України плодами та ягодами / П. В. Кондратенко, І. А. Сало // Вісник аграрної науки. - 2010. - С. 68-71.

9. Метлиикий Л. В. Основы биохимии плодов и овощей / Л. В. Метлицкий. - М. : Экономика. 1976. $-349 \mathrm{c}$.

10. Потапова А. Ю., Медютова Е. Н. Разработка элементов технологии возделывания винограда для управления его качеством при хранении / А. Ю. Потапова, Е. Н. Медютова // Перспективы развития технологий хранения и переработки плодов и ягод в современных экономических условиях : материалы междунар. науч. конф., посвященной 75-летию со дня рождения д. с-г. н. Ромуальда Эдуардовича Лойко. - Самохваловичи, 9-11 октября 2012 г. - С. 70-74.

11. Рябиева Т. В. Эффективность некорневого внесения различных водорастворимых микро- и макроудобрений и полифункционального биопрепарата Экосил в саду яблони / Т. В. Рябцева, Т. М. Костюченко, Н. Г. Капичникова // Плодоводство. - Том 21. - 2009. - С. 99-109.

12. Сологуб Ю. І., Ласинський О.А. Сучасні європейські нанотехнології та німецький досвід на ринку України - високоефективні мікродобрива Козир і Фолік / Ю. І. Сологуб, О. А. Ласинський // Овощи и фрукты. - 2015, Февраль. - С. 78.

13. Шевчук Л. М. Особливості формування якості плодів яблуні у південному Поліссі України : автореферат дис. на здобуття наукового ступеня к.с.-г.Н. - К., 2003. - 24 с.

14. Ширко Т. С., Ярошевич И. В. Биохимия и качество плодов / Т. С. Ширко, И. В. Ярошевич. Мінск : Навука і техніка, 1991. - 294 с.

15. Шуруба Г. А. Некореневое питание плодовых и ягодных культур микроэлементами / Г. А. Шаруба. - Львов : изд-во «Вища школа» при Львов. ун-те. - 1985. - 176 с. 